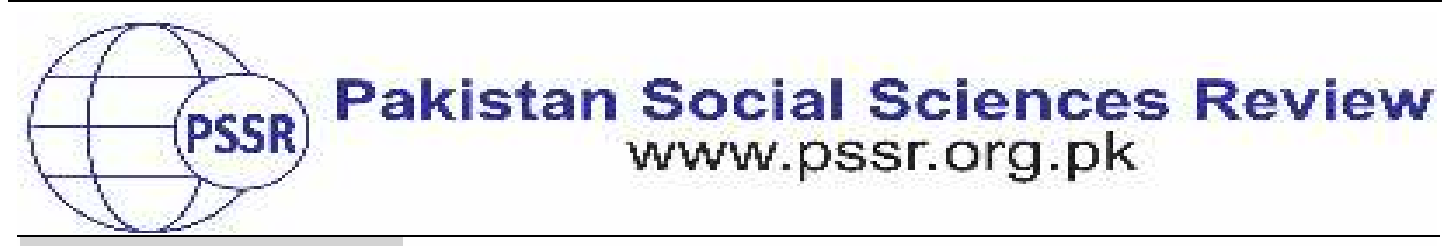

RESEARCH PAPER

\title{
Role of Research Supervisors to Implement Ethical Practices in Research of Social Sciences
}

\author{
Shahla Gul*1 ${ }^{*}$ Qaisara Parveen ${ }^{2}$ M. Imran Yousuf ${ }^{3}$
}

1. Ph.D. Research Scholar, Department of Education, PMAS-Arid Agriculture University, Rawalpindi, Punjab, Pakistan

2. Assistant Professor, Department of Education, PMAS-Arid Agriculture University, Rawalpindi, Punjab, Pakistan

3. Associate Professor, Department of Education, PMAS-Arid Agriculture University, Rawalpindi, Punjab, Pakistan

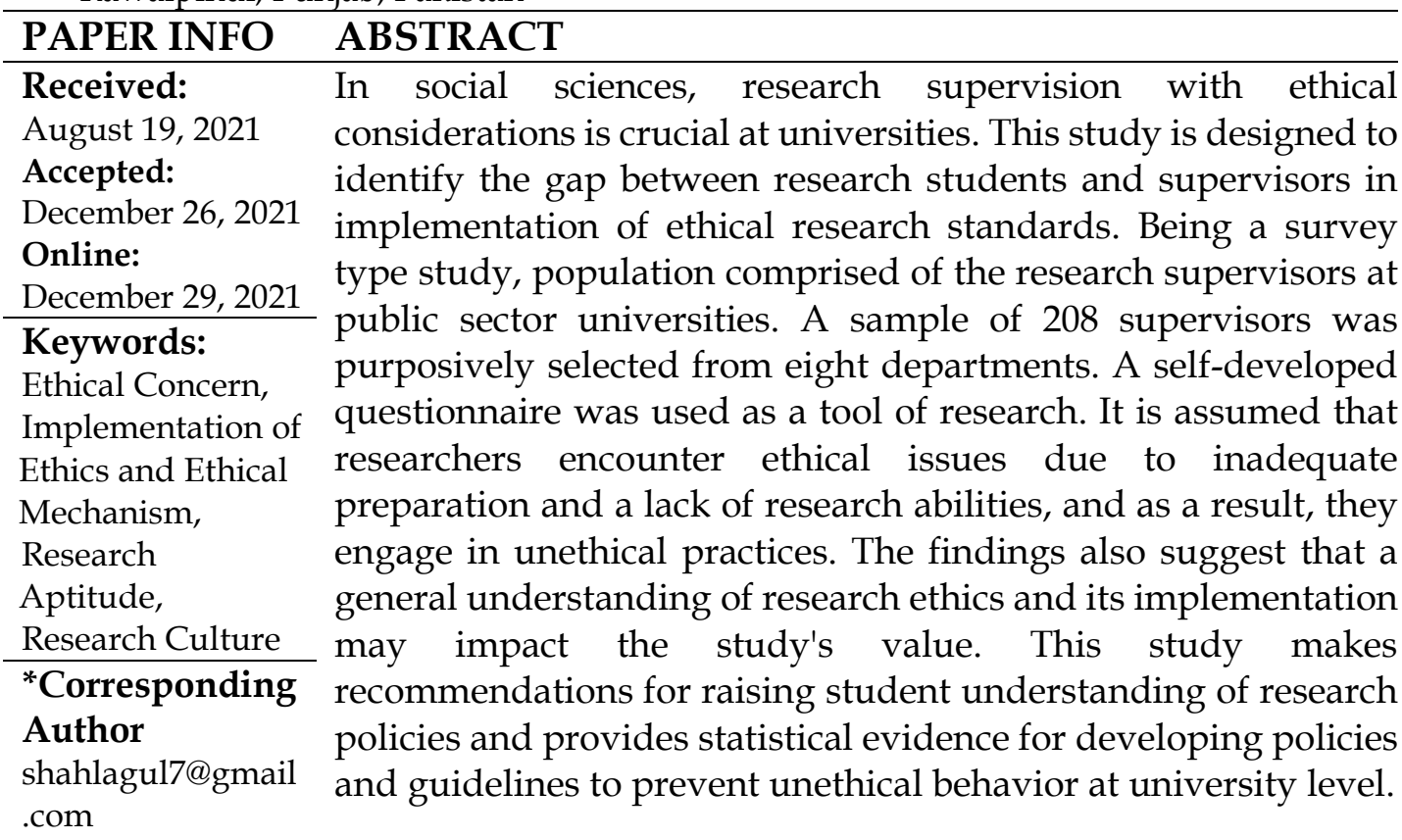

\section{Introduction}

The role of social science research in one's life and career is crucial. Plato has raised the question about ethics about two thousand years ago. On the other hand, research ethics in social science is being more demanding. Any research must include a scientific investigation as well as a business requirement. A research project's principal goal is to expand human knowledge beyond previously known (Reinhardt et al, 2015). Many of societies and economic issues can be traced back to social scientists' unethical and illegal research practices. A wide range of ethical issues is examined in the social sciences. Many professions have standard ethical guidelines for informed permission, confidentiality, avoiding harm, doing well, peer connections, and research integrity. Although this list may appear similar to 
difficulties in other scientific domains, particularly biomedicine, it is important to note that the nature and methodology of social science research include different forms of ethical risks, particularly concerning research participants. In ethical evaluation methods, social scientists frequently emphasize the need to reflect the genuine nature of these hazards. The number of students enrolled in public universities is rapidly increasing. Enrollment in Ph.D. programs has increased nearly threefold in the recent decade. The higher education commission has statutory responsibility for the standard and quality of research in higher education. The HEC has done several measures to improve the standard and ethical considerations of research in higher education.

Heather and Maley (2018) looked into how social scientists think about and practice research ethics and integrity. There are numerous elements that influence the ethical decisions during the research process. Academic discipline and culture, researcher training, teaching, research populations and participants, research methodology, the researcher's function, and data are all examples. According to Agwor and Osho (2017) ethical behavior in social science research should be needed for all types of studies. Isreal (2006) emphasized the importance of ethical considerations in qualitative research as well.

Researchers should be equipped with the knowledge and skills necessary for self-regulation that promotes research integrity (Okonta \& Rossouw, 2014). On the other hand, research institutions should cultivate responsible research ethically and discourage unethical practices of research. The norms promote the research goals of knowledge, truth, and avoidance of mistakes. Researchers need to be educated about research practice research ethics (Sen, 2016). Although research scholar's selfreported knowledge was enough, they lacked the necessary mindset. Research ethics were better understood by postgraduate students and those with research experience (Saeed, 2017).

Several ethical challenges in academia, particularly plagiarism, are rapidly becoming part of the research culture. Ramzan et al. (2012) highlighted the awareness level of students regarding plagiarism practices at the graduate and postgraduate levels. This study investigates the amount of plagiarism awareness among university students in Pakistan. Students were found to have a low level of understanding about plagiarism and institution plagiarism policies. Idiegbeyan et al, (2016) investigated the awareness and perception of students. In addition, the document offers advice for reducing plagiarism based on the authors' personal experiences. The researcher is accountable for guaranteeing research ethics while investigating social sciences. The anonymity and integrity of respondents must be protected in social science research. Sherin (2013) highlighted that role of the research ethics committee (REC) is to guarantee that research is relevant and comparable to the goals of these programs. When researchers are stressed, morally weak, and imperfect, they conduct 
unethical research. Researchers are either unaware of ethical issues or have never given them considerable consideration. Falsification of study materials, plagiarism, and fabrications are all examples of research misconduct. Image, information falsification, data suppression, and plagiarism are all types of research misconduct. Plagiarism issues arise when researchers use other people's ideas, outcomes, or comparable texts. Honest mistakes are not included in scientific misconduct. Authorship, good record keeping, intellectual property, and precise computation are all issues that researchers face today.

Mollet (2011) shed light on the ethical argument that raged in social science research. Social science scholars have various ethical concerns when conducting fieldwork in developing nations. Tangen (2014) emphasized that complex ethical dilemmas in such countries require rigorous argumentation by social science experts. Ethical considerations are becoming increasingly important in social research. Many professional organizations and government bodies have created ethical codes and regulations to guide researchers. As Mustafa (2017) mentioned that there is a fair enrolment rate in higher degree research programs in Pakistani institutions. Rehman and Waheed (2014) elaborated that there has always been a connection between research integrity and research supervision in the research world. Research supervision aims to help students develop critical, creative thinking, and research abilities while also contributing to the body of information already in existence (Anderson et al. 2006). It necessitates a wide range of supervisory abilities. In other words, the quality of the work produced is influenced to some part by the quality of supervision, such as supervisory style and the learning needs and patterns of the students (Hemer, 2012). Gul et al. (2018) examined the awareness level of students regarding ethical practices. The results also indicated that a low level of awareness affects the research standards. Research students did not care about the ethical norms of research. Students fail to observe ethical concerns due to their various difficulties. Research quality can be improved by observing standard ethical practices.

\section{Material and Methods}

As the research was descriptive in nature, so survey was preferred as design of this research. Quantitative research approach was applied in order to achieve the said purpose (Collins et al., 2007; Tayraukham, 2009). However, different practices were focused on previous researches.

\section{Sample}

At first stage, four public sector universities were selected randomly. Eight departments were purposively selected from the social sciences. The supervisors from each of eight departments were purposively considered as a sample. In this way a sample of 208 research supervisors was available for their participation in this 
research survey. The main focus of this study was at ethical practices adopted by the supervisors during the research. The researcher wanted to understand the actual situation of the research, so only those faculty members were involved in this study, who were having research supervision.

\section{Research Tool}

According to this study's objectives, the data collection procedure has been completed by observing the following protocol.

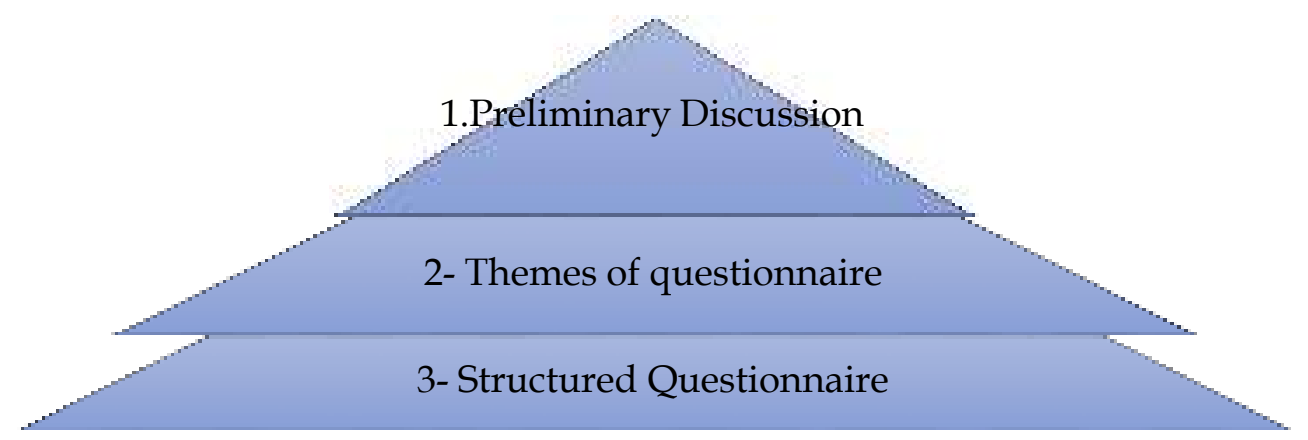

Figure 1: Data collection protocol

To assess research supervisors' perceptions regarding the attitude of research students towards the implementation of ethical consideration in their research and how they observed research standards. The themes of questionnaires are shown in figure 2 .

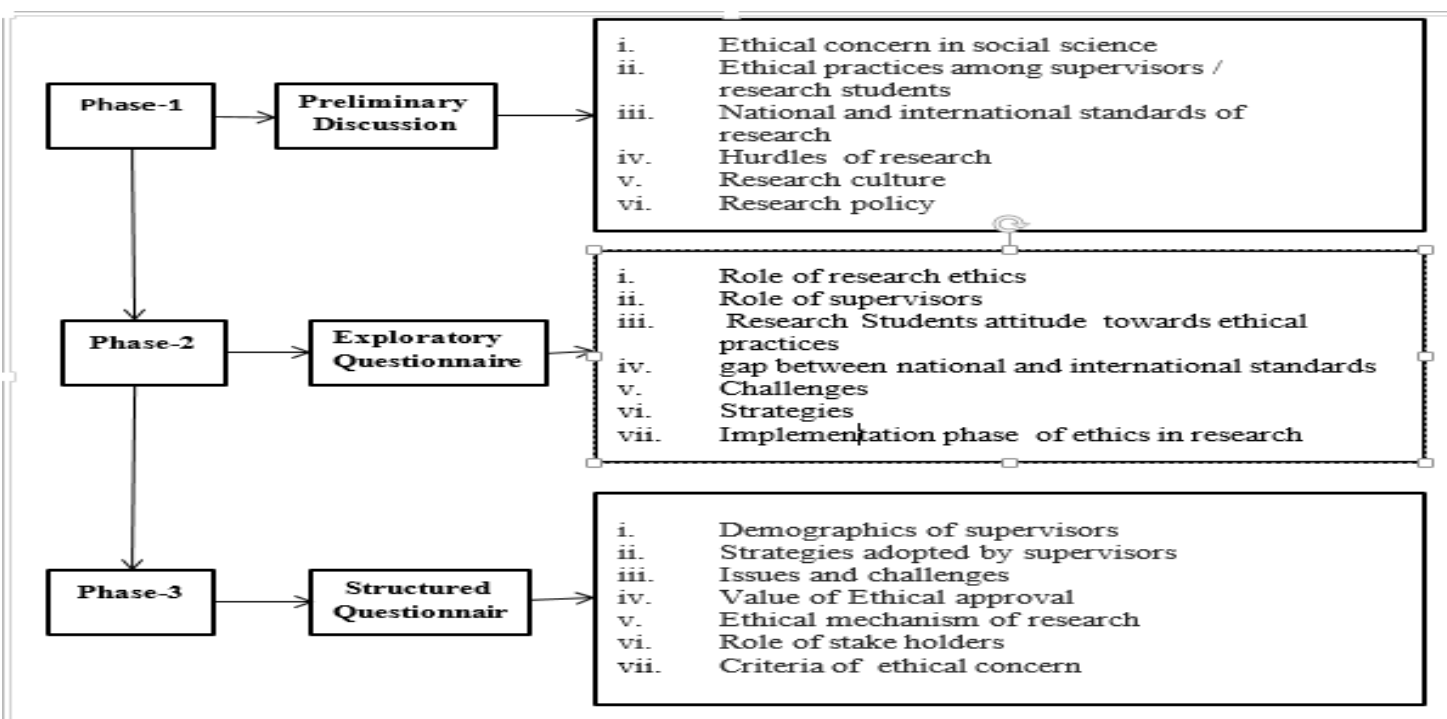

Figure 2: Themes of Questionnaires 
Following baseline themes were displayed before the supervisors before their responses to the questionnaire. A structured questionnaire for supervisors was developed based on responses to baseline exploratory questionnaire. Baseline themes were shared with respondents before the completion of their responses of structured questionnaires. There were different types of items including the demographic information of the respondents. The supervisor's demography, challenges during implementations and future strategies-based questions were included in this questionnaire. Initially self-developed questionnaire was validated through experts' opinion. However, the reliability of the questionnaire was found to be 0.71 .

\section{Results and Discussion}

The data analysis consisted of two sections, the data of close ended items was analyzed using descriptive (percentages, mean, SD) through SPSS's latest version. Whereas for open ended items the responses were categorized into respective themes. Responses were interpreted by shifting the experiences of supervisors into a meaningful theme.

\section{Section I- Quantitative Data}

The researcher collected data from the research supervisors through a questionnaire. The demographics of respondents are given in the table as mentioned below.

Table 1

Demographic data of supervisors

\begin{tabular}{cccc}
\hline D-V & $\mathbf{S}-\mathbf{V}$ & $\mathbf{F}$ & $\mathbf{0}$ \\
\hline \multirow{3}{*}{ Experience } & $6-10$ & 81 & 39 \\
\cline { 2 - 4 } & $11-15$ & 84 & 40 \\
\cline { 2 - 4 } Departments & $15-$ onwards & 43 & 18 \\
\cline { 2 - 4 } & Education & 32 & 16 \\
\cline { 2 - 4 } & Sociology & 24 & 11 \\
\cline { 2 - 4 } & Economics & 26 & 17 \\
\cline { 2 - 4 } & Pakistan studies & 34 & 13 \\
\cline { 2 - 4 } & Mass-com & 16 & 8 \\
\cline { 2 - 4 } & Islamic studies & 33 & 13 \\
\cline { 2 - 4 } & Anthropology & 27 & 16 \\
\cline { 2 - 4 } & Psychology & &
\end{tabular}

Table 1 demonstrates that in this study, 39\% research supervisors have 6 to 10 years, $40 \%$ have 11 to 15 years of experience; however, $18 \%$ have more than 15 years 
of research experience. Eight departments of the social sciences faculty and their respective supervisors are mentioned in the above-given table.

Table 2

Adoption of ethical practices by institutions

\begin{tabular}{|c|c|c|c|c|c|c|c|}
\hline \multirow{2}{*}{ Items } & \multicolumn{5}{|c|}{ Responses Frequency (\%) } & \multirow{2}{*}{ Mean } & \multirow{2}{*}{ SD } \\
\hline & SDA & DA & UNC & A & SA & & \\
\hline $\begin{array}{l}\text { Research rules depict clear } \\
\text { understanding in practice. }\end{array}$ & $\begin{array}{c}22 \\
(11)\end{array}$ & $\begin{array}{l}50 \\
(24)\end{array}$ & $\begin{array}{c}70 \\
(34)\end{array}$ & $\begin{array}{c}43 \\
(21) \\
\end{array}$ & $\begin{array}{c}23 \\
(11)\end{array}$ & 2.97 & 1.14 \\
\hline $\begin{array}{l}\text { The research environment is so } \\
\text { supportive to motivate } \\
\text { researchers for ethical practices. }\end{array}$ & $\begin{array}{c}82 \\
(40)\end{array}$ & $\begin{array}{c}66 \\
(32)\end{array}$ & $\begin{array}{l}41 \\
(20)\end{array}$ & $\begin{array}{c}5 \\
(2)\end{array}$ & $\begin{array}{l}14 \\
(7)\end{array}$ & 2.05 & 1.13 \\
\hline $\begin{array}{l}\text { Ethical training is conducted for } \\
\text { teachers. }\end{array}$ & $\begin{array}{c}5 \\
(2) \\
\end{array}$ & $\begin{array}{l}37^{\prime} \\
(18)\end{array}$ & $\begin{array}{c}31 \\
(15)\end{array}$ & $\begin{array}{l}100 \\
(48)\end{array}$ & $\begin{array}{c}35 \\
(17)\end{array}$ & 3.59 & 1.04 \\
\hline $\begin{array}{l}\text { Up to date research policy is } \\
\text { available. }\end{array}$ & $\begin{array}{c}5 \\
(2) \\
\end{array}$ & $\begin{array}{c}39 \\
(19) \\
\end{array}$ & $\begin{array}{c}28 \\
(14)\end{array}$ & $\begin{array}{c}88 \\
(42) \\
\end{array}$ & $\begin{array}{c}48 \\
(23) \\
\end{array}$ & 3.64 & 1.10 \\
\hline $\begin{array}{l}\text { Research ethics boards are not } \\
\text { fully functional. }\end{array}$ & $\begin{array}{c}25 \\
(12)\end{array}$ & $\begin{array}{c}24 \\
(12)\end{array}$ & $\begin{array}{l}34 \\
(16)\end{array}$ & $\begin{array}{c}93 \\
(45)\end{array}$ & $\begin{array}{c}32 \\
(15)\end{array}$ & 3.39 & 1.22 \\
\hline $\begin{array}{l}\text { More extensive research reforms } \\
\text { are implemented from time to } \\
\text { time. }\end{array}$ & $\begin{array}{l}19 \\
(9)\end{array}$ & $\begin{array}{l}19 \\
(9)\end{array}$ & $\begin{array}{c}20 \\
(10)\end{array}$ & $\begin{array}{l}103 \\
(50)\end{array}$ & $\begin{array}{l}47 \\
(23)\end{array}$ & 3.67 & 1.18 \\
\hline $\begin{array}{l}\text { Ethical clearance of study } \\
\text { completed before conducting of } \\
\text { research. }\end{array}$ & $\begin{array}{l}11 \\
(5)\end{array}$ & $\begin{array}{l}33 \\
(16)\end{array}$ & $\begin{array}{c}41 \\
(20)\end{array}$ & $\begin{array}{c}90 \\
(43)\end{array}$ & $\begin{array}{l}33 \\
(16)\end{array}$ & 3.48 & 1.09 \\
\hline $\begin{array}{l}\text { Ethical practices are evaluated in } \\
\text { line with the resource. }\end{array}$ & $\begin{array}{c}4 \\
(2)\end{array}$ & $\begin{array}{c}22 \\
(11)\end{array}$ & $\begin{array}{c}30 \\
(14)\end{array}$ & $\begin{array}{l}104 \\
(50)\end{array}$ & $\begin{array}{l}48 \\
(23)\end{array}$ & 3.81 & .970 \\
\hline
\end{tabular}

Table 2 shows the perceptions of research supervisors regarding the institution's adoption of ethical practices of research.

1) One-third of research supervisors considered that research rules at the institution did not depict a clear understanding in practice because research students know research rules but are unable to follow such rules being clear.

2) The majority of the respondents did not agree that the research environment is so supportive to motivate researchers for ethical practices, but in this case, researchers are not satisfied with the current research scenario in universities. Only a nice percent was satisfied with the role of the research environment of universities is supportive.

3) One-third of research supervisors considered that ethical training is conducted for teachers in universities the mean score is 3.59 winch is supportive for trainings session are helpful to promote research ethics in social sciences. 
4) The mean score is 3.64. The results support that universities provided up-todate research policies to the research committees. The research policy is always available on the university website.

5) One-third of respondents support that research ethics boards are not fully functional in their institutions. The mean score is 3.39 also supports their views.

6) The mean score is 3.67 of this statement that more extensive research reforms are implemented from time to time. The majority of the respondents agreed that the universities are implementing research reforms.

7) The majority of the respondents agreed that ethical clearance of any study is completed before conducting research. The mean score of 3.48, the mean score, supports the result.

8) Ethical practices are evaluated in line with the resource. The mean score of 3.81 supports the result. Resources are helpful for standard research.

Table 3

Supervision of ethical practices by supervisors

\begin{tabular}{|c|c|c|c|c|c|c|c|}
\hline \multirow{2}{*}{ Items } & \multicolumn{5}{|c|}{ Responses Frequency (\%) } & \multirow{2}{*}{ Mean } & \multirow{2}{*}{ SD } \\
\hline & SDA & DA & UNC & A & SA & & \\
\hline $\begin{array}{l}\text { Research standards help us to } \\
\text { keep pace with the modern, } \\
\text { rapidly changing world }\end{array}$ & $\begin{array}{c}6 \\
(3)\end{array}$ & $\begin{array}{c}25 \\
(12)\end{array}$ & $\begin{array}{l}41 \\
(20)\end{array}$ & $\begin{array}{c}76 \\
(37)\end{array}$ & $\begin{array}{l}60 \\
(29)\end{array}$ & 3.76 & 1.08 \\
\hline $\begin{array}{l}\text { The gradual change from the } \\
\text { initial level of research }\end{array}$ & $\begin{array}{c}0 \\
(0)\end{array}$ & $\begin{array}{c}39 \\
(19)\end{array}$ & $\begin{array}{c}38 \\
(18)\end{array}$ & $\begin{array}{c}73 \\
(35)\end{array}$ & $\begin{array}{c}58 \\
(28)\end{array}$ & 3.72 & 1.06 \\
\hline $\begin{array}{l}\text { Course work has a sufficient basis } \\
\text { for critical and analytical } \\
\text { reasoning-based activities. }\end{array}$ & $\begin{array}{l}10 \\
(5)\end{array}$ & $\begin{array}{l}60 \\
(29)\end{array}$ & $\begin{array}{l}105 \\
(51)\end{array}$ & $\begin{array}{l}17 \\
(8)\end{array}$ & $\begin{array}{l}16 \\
(8)\end{array}$ & 2.85 & .923 \\
\hline $\begin{array}{l}\text { Supervisors convey information } \\
\text { about research ethics to their } \\
\text { students. }\end{array}$ & $\begin{array}{l}15 \\
(7)\end{array}$ & $\begin{array}{c}25 \\
(12)\end{array}$ & $\begin{array}{l}50 \\
(24)\end{array}$ & $\begin{array}{c}86 \\
(41)\end{array}$ & $\begin{array}{c}32 \\
(16)\end{array}$ & 3.45 & 1.11 \\
\hline $\begin{array}{l}\text { Supervisors are providing a copy } \\
\text { of the research policy to students. }\end{array}$ & $\begin{array}{c}20 \\
(10)\end{array}$ & $\begin{array}{c}31 \\
(15)\end{array}$ & $\begin{array}{c}34 \\
(16)\end{array}$ & $\begin{array}{c}90 \\
(43)\end{array}$ & $\begin{array}{c}33 \\
(16)\end{array}$ & 3.40 & 1.20 \\
\hline $\begin{array}{l}\text { The involvement of teachers is } \\
\text { necessary for the planning of } \\
\text { research policy. }\end{array}$ & $\begin{array}{c}2 \\
(1)\end{array}$ & $\begin{array}{c}35 \\
(17)\end{array}$ & $\begin{array}{l}119 \\
(57)\end{array}$ & $\begin{array}{c}34 \\
(16)\end{array}$ & $\begin{array}{l}18 \\
(9)\end{array}$ & 3.37 & 1.57 \\
\hline $\begin{array}{l}\text { The supervisor keep check and } \\
\text { balance on the research project }\end{array}$ & $\begin{array}{c}23 \\
(11)\end{array}$ & $\begin{array}{l}50 \\
(24)\end{array}$ & $\begin{array}{c}23 \\
\text { (11) }\end{array}$ & $\begin{array}{c}62 \\
(30)\end{array}$ & $\begin{array}{c}50 \\
(24)\end{array}$ & 3.31 & 1.36 \\
\hline
\end{tabular}

Table 3 indicates supervisors' perceptions regarding the adoption of ethical norms to promote ethical practices among their research students. 
1) The mean score of 3.76 supports the results that Research standards help us keep pace with the rapidly changing world. Students can take help from research rules.

2) The mean score is 3.72, which shows that change is required in this technological period, but Gradual change from the initial level of research can change the whole research scenario.

3) Course work has a sufficient basis for critical and analytical reasoning-based activities, but the mean score of 2.85 did not support this statement. Course works of higher degrees are part of the research. But analytical-based assignments are not part of the research.

4) Supervisors convey information about research ethics to their students. The mean score of 3.45 of this statement supports the results that the complete knowledge of research ethics is provided to the research students.

5) Supervisors provide the research policy to their students. The mean score of 3.40 supports this statement. Students have how to know about research policy.

6) The role of teachers cannot be ignored to make a standard policy of research. The involvement of teachers can reflect the whole process of research. In this regard, the mean score is 3.37 .

7) The mean score is 3.31, which shows that supervisors keep check and balance on a research project the research become refined and maintain standard in social sciences.

Table 4

Reflection of ethical practices by research students

\begin{tabular}{|c|c|c|c|c|c|c|c|}
\hline \multirow{2}{*}{ Items } & \multicolumn{5}{|c|}{ Responses Frequency (\%) } & \multirow{2}{*}{ Mean } & \multirow{2}{*}{ SD } \\
\hline & SDA & DA & UNC & A & SA & & \\
\hline $\begin{array}{l}\text { Researchers are fully aware about } \\
\text { the values of respect, tolerance } \\
\text { and understanding. }\end{array}$ & $\begin{array}{c}4 \\
(2)\end{array}$ & $\begin{array}{c}56 \\
(27)\end{array}$ & $\begin{array}{l}73 \\
(35)\end{array}$ & $\begin{array}{c}63 \\
(30)\end{array}$ & $\begin{array}{l}12 \\
(6)\end{array}$ & 3.11 & .933 \\
\hline $\begin{array}{c}\text { Supervisors develop research } \\
\text { aptitude.. }\end{array}$ & $\begin{array}{c}38 \\
(18)\end{array}$ & $\begin{array}{c}35 \\
(17)\end{array}$ & $\begin{array}{c}45 \\
(22)\end{array}$ & $\begin{array}{c}81 \\
(39) \\
\end{array}$ & $\begin{array}{c}9 \\
(4)\end{array}$ & 2.94 & 1.21 \\
\hline $\begin{array}{l}\text { Adaptation of cooperative } \\
\text { behavior and motivational } \\
\text { techniques }\end{array}$ & $\begin{array}{l}30 \\
(14)\end{array}$ & $\begin{array}{c}41 \\
(20)\end{array}$ & $\begin{array}{l}70 \\
(34)\end{array}$ & $\begin{array}{c}4 \\
(2)\end{array}$ & $\begin{array}{c}63 \\
(30)\end{array}$ & 3.13 & 1.41 \\
\hline $\begin{array}{l}\text { Researchers are lacking in } \\
\text { research skills and interest in } \\
\text { research. }\end{array}$ & $\begin{array}{l}53 \\
(26)\end{array}$ & $\begin{array}{c}28 \\
(14)\end{array}$ & $\begin{array}{l}18 \\
(9)\end{array}$ & $\begin{array}{l}19 \\
(9)\end{array}$ & $\begin{array}{c}90 \\
(43)\end{array}$ & 3.31 & 1.70 \\
\hline $\begin{array}{l}\text { Students are willing to keep } \\
\text { involved themselves to monitor } \\
\text { research works and make them }\end{array}$ & $\begin{array}{c}61 \\
(29)\end{array}$ & $\begin{array}{l}76 \\
(37)\end{array}$ & $\begin{array}{c}52 \\
(25)\end{array}$ & $\begin{array}{c}6 \\
(3)\end{array}$ & $\begin{array}{l}13 \\
(6)\end{array}$ & 2.20 & 1.08 \\
\hline
\end{tabular}




\begin{tabular}{cccccccc}
\hline $\begin{array}{c}\text { effective and provide timely } \\
\text { feedback }\end{array}$ & & & & & & & \\
\hline $\begin{array}{c}\text { Students are more concerned } \\
\text { about the timely provision of } \\
\text { evaluation reports }\end{array}$ & $\begin{array}{c}27 \\
(13)\end{array}$ & $\begin{array}{c}11 \\
(5)\end{array}$ & $\begin{array}{c}76 \\
(37)\end{array}$ & $\begin{array}{c}14 \\
(7)\end{array}$ & $\begin{array}{c}80 \\
(39)\end{array}$ & 3.52 & 1.38 \\
\hline $\begin{array}{c}\text { Unethical practices of researchers } \\
\text { are timely reported. }\end{array}$ & 3 & 59 & 48 & 29 & 69 & 3.49 & 1.25 \\
& $(1)$ & $(29)$ & $(23)$ & $(14)$ & $(33)$ & & \\
\hline
\end{tabular}

Table 4 indicates supervisors' perceptions regarding the Reflection of ethical practices by research students.

1) Researchers are fully aware of the values of respect, tolerance, and understanding. They have how to know about the ethical norms of research. The mean score of 3.11 represents that respect of moral values and tolerance of researchers makes research effective.

2) Supervisors are role models for their students. They try to develop research aptitude in them. The mean score is 2.49 , which supports supervisors' role in promoting research ethics among their students.

3) The mean score is 3.13, revealing that motivational techniques can increase studies' worth, especially for their students. The attitude is aggressive the output of research can be affected. But the corporation between supervisors and their supervisees can solve the issues related to the research project.

4) Researchers are lacking in research skills and research interests. The mean score is 3.31, which shows that students need to be interested in their research work. Research skills should be polished.

5) The mean score is 2.20. Students are willing to keep involved themselves, Monitor research works and make it effective and provide timely feedback, but students are not satisfied with the criticism.

6) Students are more concerned about the timely provision of evaluation reports. The mean score is 3.52reveals that evolution reports should be provided in time to the concerned students

7) Unethical practices of researchers are timely reported. The mean score of 3.49 shows that these unethical practices are not reported in time, but these are not discussed with the students. The research advisors did not take importance to penalize this type of discussion. 
Table 5

Perceived level of satisfaction regarding stakeholders of research

\begin{tabular}{lcccc}
\hline \multicolumn{1}{c}{ Satisfaction level } & $\begin{array}{c}\text { FS } \\
\mathbf{f ~ ( \% )}\end{array}$ & $\begin{array}{c}\text { PS } \\
\mathbf{f ~ ( \% )}\end{array}$ & $\begin{array}{c}\text { NS } \\
\mathbf{f ~ ( \% )}\end{array}$ & Mean \\
\hline Attitude of students & $48(23)$ & $78(37)$ & $82(39)$ & 1.83 \\
\hline Attitude of Supervisors & $65(31)$ & $60(29)$ & $83(39)$ & 1.91 \\
\hline Role of Administration & $30(15)$ & $80(38)$ & $98(47)$ & 1.67 \\
\hline Supervisory committee & $34(17)$ & $65(31)$ & $109(52)$ & 1.63 \\
\hline Role of HEC & $62(30)$ & $88(42)$ & $58(28)$ & 2.01 \\
\hline Role of QEC & $56(27)$ & $74(35)$ & $78(37)$ & 1.89 \\
\hline Total $(\%)$ & $24 \%$ & $36 \%$ & $41 \%$ & 100 \\
\hline
\end{tabular}

Six stakeholders have been identified in table 5: the responses of respondents are given in percentages as they understand their role to implementation ethical practices in research. These stakeholders are research students, supervisors, administration, supervisory committee, HEC and quality enhancement cells. The responses regarding their role in ethical principles in research have been analyzed. These responses have been measured in percentages along with frequencies. 30\% were satisfied with the initiatives taken by HEC. However, $42 \%$ were partially satisfied with these policies. But $28 \%$ were not satisfied with the role of HEC. It is also measured that supervisors are not satisfied with the student's attitude. 39\% were not satisfied with it, and $37 \%$ were partially satisfied with the students' role. According to $31 \%$, the role of supervisory committees was satisfactory. $52 \%$ were not satisfied with their performance. $27 \%$ were fully satisfied with quality enhancement cells' role, although $37 \%$ were not pleased. $31 \%$ highlighted the responsible role of supervisors regarding ethical guidelines.

\section{Section 2: Analysis of open ended items}

In this part researcher collected data through the preliminary discussion guidelines of the supervisors and the explanatory questionnaire of the research supervisors is analyzed and presented hereunder.

Table 6

Perception of supervisors regarding the role of research ethics

\begin{tabular}{cl}
\hline & \multicolumn{1}{c}{ Themes of the exploratory Questionnaire } \\
\hline i. & Role of the code of ethics in the research of social sciences \\
\hline ii. & $\begin{array}{l}\text { The attitude of Supervisors and research students towards ethical } \\
\text { practices }\end{array}$ \\
\hline iii. & The gap between research policy and its implementation \\
\hline iv. & Strategies of standard research adopted by the supervisors \\
\hline v. & Challenges faced by supervisors to implement research ethics \\
\hline
\end{tabular}


vi.

Mechanism-based on research ethics

Research supervisors' opinions on the ethical practice of analysis adopted by research students have been examined in this scenario. Table 6 gives detailed description of supervisors' perceptions regarding the themes of this questionnaire. The focus of this type of data was based on the existing situation of research in public universities. The findings of qualitative data have been given in three themes which are the importance of ethical mechanism, factors affecting the standards of research, and development of an ethical mechanism.

\section{Importance of Ethical Mechanism}

The role of supervisors to promote research ethics was considered satisfactory. Higher Education Commission (HEC) is responsible for implementing research standards in public universities. The quality enhancements cells pay special attention to standards of research but researchers don't take legitimate thoughtfulness regarding moral standards. A few of the researchers ready to get familiar with these standards. They were conscious of applying these standards to research. The majority of the research scholars dismisses and explores moral arrangements since they are not entirely mindful about its research usage.

The general role of supervisors is to guide and assist students during their period of research. The supervisor and the examiner's roles are quite distinct, and it is not one of the supervisor's roles to assess the thesis. Universities follow HEC approved policy regarding research. Every standard is defined. Quality enhancements cells are introduced at the university level to kept check and balance on research work. The researchers and supervisors have to keep in mind all the ethical considerations before the research.

\section{Factors Affecting the Standards of Research}

Research supervisors identified the factors of unethical attitudes of researchers regarding research. There are many reasons behind the unethical stance of research towards social sciences research. The lack of students' motivation compounds the reason for research misconduct. It is moderately attributable to lack of prerequisite research skills, limited access to information technology, low prop up due to heavy staff, and student workload. Besides, little understanding of research, inadequate research capacity tied with a no supportive supervisory relationship is more likely to escort loss of student's confidence in supervisors. The students take ethical practices as the formality of the study thesis into account. It was suggested that, due to the lack of facilities, they face difficulties implementing this ethical strategy, digital laboratories are not available, and two teachers suggested that financial strain has hindered institutions in providing material and infrastructure 
support to teachers. It was very challenging for three teachers to declare teachingrelated challenges. The participants made some statements and concerns about implementing the research standard program. The research supervisors face many ethical issues during their supervision because the research students are not competent because they did not pay proper attention to their research work.

\section{Development of an Ethical Mechanism}

Ethical standards are fundamental importance to higher education institutions and have consequences for educational change. The main factor in a research project's success is the supervisor's and researchers' partnership. Every step of the research should be planed and supervisor should assess the ethical aspects of the study. Up-to-date information is needed for ethical consideration. The research program should be regularly tracked. Writing skills should be sophisticated through the use of different techniques. The supervisor should work on practical aspects of research rather than its text formatting. There should be an appropriate check and balance system. The university should make conventions and regulations for researchers. They should try to perk up the skill and knowledge through the seminar, workshop, and conference. Research writing should learn from researchers initially and try to assemble confidence in them. The majority of supervisors said that there is a problem with time management with them. Besides, there are plenty of students and courses enrolled. For students, the classrooms may be healthy yet the number of research students is abundant to deal with their supervision. Managing the classes, as well as research students, is challenging.

\section{Conclusion}

The role of supervisors is significant in implementing ethical standards in research. The research aptitude of students can affect the quality of research. A gap was identified between research policy and its implementation, especially in social science. Students are conscious of ethical practices when the nature of the study is experimental. Supervisors' attitude towards research ethics matters, especially to promote ethical practices Challenges were also addressed in the implementation of research standards. Supervisors can design a uniform mechanism based on research standards. Coordination and cooperation are required between administration, supervisors, and research students. Research supervisors adopted different strategies to promote ethical practices among their respective research students. Students learn techniques from the research environment of the university. Quality enhancement cells are working to promote research standards in the universities of Pakistan. Supervisors need to use different assessment techniques to assess students' ethical practices, Universities have a comprehensive research policy, and research rules are given with clarity, but students are not taking it as their universities require, and the environment of research is not supportive of promoting ethical research practices. 
Research ethics boards are not fully functional because no separate boards are introduced to review ethical practices of research in the context of social sciences. The role of research students to promote ethical consideration is not satisfactory as it is alarming.

The majority of the respondents agreed with these initiatives adopted by the supervisors. Although respondents were not satisfied that analytical and critical reasoning-based assignments are part of coursework. Supervisors try to keep check and balance on their student's research projects. Most of the supervisors did not make research policy, so the gap between policy and its implementation has also been observed. Although Research supervisors provide complete information regarding ethical practices and students know the ethical values of research. Research supervisors try to create research aptitude in students by adopting different motivational techniques. Students are unwilling to keep involving them in monitoring research works, making it effective, and providing timely feedback. The supervisors are willing to identify unethical practices and the serious research misconducts are reported to the concerned authorities.

\section{Recommendations}

i. Professional attitude should be adopted by the researchers to supervise any kind of study. There is a need to develop research aptitude in research students. The trend towards unethical practices has decreased to follow ethical practices in research.

ii. Ethics of social science are taught to work independently. The Researcher needs to improve their communication skills and develop research aptitude. Ethical issues are also identified because of avoiding the moral norm of research in social sciences. Students understand the value of ethics in research, but most research students are concerned about these standards at the end of their work.

iii. The majority of students agreed that ethical research practices should be part of coursework. There is a need to provide complete guidelines to research before conducting research. The responsible role of research stakeholders can be improved the quality of research in social sciences. 


\section{References}

Agwor, T. C., \& Osho, A. A. (2017). Ethical Issues for consideration in researching the social and behavioral sciences. International Journal of Humanities $\mathcal{E}$ Social Studies, 5(12), 185-188.

Anderson, C., Day, K., \& McLaughlin, P. (2006). Mastering the dissertation: Lecturers' representations of the purposes and processes of master's level dissertation supervision. Studies in Higher Education, 31(2), 149-168.

Collins, K. M., Onwuegbuzie, A. J., \& Jiao, Q. G. (2007).A mixed-methods investigation of mixed methods sampling designs in social and health science research. Journal of Mixed Methods Research,1(3), 267-294.

Gul, S., Parveen, Q., \& Yousuf, M. I. (2018). Ethics of conducting research in social sciences at the university level in Pakistan. Global Social Sciences Review, 3(4), 486 $-497$.

Hafaiedh, A. B. (2009). Research ethics for social scientists: between ethical conduct and regulatory compliance by Mark Israel and Lain Hay. International Social Science Journal, 60(197), 467-472.

Heather, C. S., \& Maley, M. (2018). Automated direct screening for resistance of gramnegative blood cultures using the BD Kiestra Work Cell. European Journal of Clinical Microbiology Eamp; Infectious Diseases, 37(1), 117-125.

Hemer, S. R. (2012). Informality, power and relationships in postgraduate supervision: Supervising Ph.D. candidates over coffee. Higher Education Research $\mathcal{E}$ Development, 31(6), 827-839

Idiegbeyan-Ose, J., Nkiko, C., \& Osinulu, I. (2016). awareness and perception of plagiarism of postgraduate students in selected universities in ogun state, Nigeria. Library Philosophy and Practice.

Isreal, M., \& Hay, I. (2006). Research ethics for social scientists: London: Sage.

Mollet, J. (2011). Ethical issues in social science research in developing countries: Useful or symbolic. In Transmission of academic values in Asian Studies workshop (2009: Australian National University, Canberra, ACT). The Australia-Netherlands Research Collaboration (ANRC).

Mustafa, G. (2017). Indicators for quality in higher education: Comparison between Pakistan and Germany. The Online Journal of Quality in Higher Education, 4(3) 
Okonta, P. I., \& Rossouw, T. (2014). Misconduct in research: a descriptive survey of attitudes, perceptions and associated factors in a developing country. BMC Medical Ethics, 15(1), 25-31.

Punch, K. F. (2013). Introduction to social research: Quantitative and qualitative approaches. Sage.

Ramzan, M., Munir, M. A., Siddique, N., \& Asif, M. (2012). Awareness about plagiarism amongst university students in Pakistan. Higher Education, 64(1), 7384.

Rehman, R. R., \& Waheed, A. (2014). Ethical perception of university students about academic dishonesty in Pakistan: identification of student's dishonest acts. The Qualitative Report, 19(4), 1-13.

Reinhardt, W., Mletzko, C., Sloep, P. B., \& Drachsler, H. (2015). Understanding the meaning of awareness in research. Available at ceur-ws.org, 931.

Saeed, A. (2017). Association of research ethics knowledge with previous research exposure and academic qualification among food and nutrition graduates in Pakistan. Kmuj: Khyber Medical University Journal, 9(3), 140-145.

Sen, V. (2016). Ethical Issues in social science research. Research Journal of Management, 5(10), 37-41.

Sherin, A. (2013). Research ethics committees (RECs) and monitoring of biomedical research in Pakistan. Khyber Medical University Journal, 5(3), 121-2

Shirazi, B., Jafarey, A. M., \& Moazam, F. (2010). Plagiarism and the medical fraternity: a study of knowledge and attitudes. JPMA. The Journal of the Pakistan Medical Association, 60(4), 269.

Tayraukham, S. (2009). Academic ethics in research methodology. The Social Sciences, $4(6), 573-577$.

Tangen, R. (2014). Balancing ethics and quality in educational research - the ethical matrix method. Scandinavian Journal of Educational Research, 58(6), 678-694. 